\title{
Exploration of Cultivating Business English Talents of Maritime University_-Taking Zhejiang Ocean University as an Example
}

\author{
Xuanqi Wang \\ Zhejiang Ocean University, Zhoushan, China \\ Fangjie He \\ Zhejiang Ocean University, Zhoushan, China
}

\begin{abstract}
With the construction of Zhoushan Free Trade Zone and settlement of Boeing project, internationalization has brought new opportunities to Zhoushan's foreign trade industries, vigorously promoted Zhoushan's marine economy into rapid development, and put forward higher request to the cultivation of Business English talents. But based on the current social reality, there exist few international Business English talents who both have the ability of language and operation. Zhoushan's marine industries' development is entering a new era of internationalization. If we can cultivate Business English talents who both have the ability of language and operation, we will be sure to break through the bottleneck of Zhoushan's marine industries towards the world. Based on current situation of Business English talents training, this thesis takes Zhejiang Ocean University as an example to make positive contribution to exploring innovative talents training modes of Business English major in maritime universities and promoting the development of Zhoushan's marine economy. This thesis can be divided into 3 parts. Part 1 introduces the background, significance and current situation on cultivating Business English talents of maritime universities. Part 2 is an experimental research on current situation of cultivating Business English talents in Zhejiang Ocean University. And some suggestions on cultivating Business English talents of maritime universities are mentioned in part 3.
\end{abstract}

Index Terms-Business English, Maritime Universities, talents training, innovative training modes

\section{INTRODUCTION}

Business English major aims to cultivate compound and applicable talents who have a solid foundation in English with international perspectives and humanistic qualities, master basic theories and knowledge of Linguistics, Economics, Management, Law (International Commercial Law), and are familiar with the rules and conventions of international business with English application ability, business operation ability, cross-cultural communication ability, speculative and creative ability and independent learning ability. It is the goal of Business English major to cultivate compound and applicable talents who have a solid foundation in English with international perspectives and humanistic qualities, master basic theories and knowledge of Linguistics, Economics, Management, Law (International Commercial Law), and are familiar with the rules and conventions of international business with English application ability, business operation ability, cross-cultural communication ability, speculative and creative ability and independent learning ability. In view of the training modes of Business English talents, many experts at home and abroad have done researches, put forward valuable ideas, and pointed out instructive directions for cultivating Business English talents. However, Business English talents training are far behind the development of culture, economy and politics currently.

Therefore, in order to innovate Business English talents training modes and promote the development of Zhoushan's marine industries, based on existing researches at home and abroad, this thesis attempts to analyze curriculum construction, teaching content and reform methods of Business English major in marine universities. And this thesis mainly takes Zhejiang Ocean University as an example to make positive contribution to exploring innovative talents training modes of Business English major in marine universities, and promoting the development of Zhoushan's marine economy. This thesis are divided into 3 parts. Part 1 introduces the background, significance and current situation on cultivating Business English talents of maritime universities. Part 2 is an experimental research on current situation of cultivating Business English talents in Zhejiang Ocean University. And some suggestions on cultivating Business English talents of maritime universities are mentioned in part 3.

\section{Current Situation on Cultivating Business English Talents of Maritime University}

Since Business English major was approved to be set by the Ministry of Education, this major has gone into the process of rapid growth. How to cultivate Business English talents has become a hot topic in society. In recent years, many universities have actively explored the reform of English major and set up Business English major to provide 
more compound language talents to the competitive market. Through years of exploration, the Business English training modes has been into the initial stage. Business English major now mainly use case study and practical teaching as useful ways to establish a curriculum system of Business English major, that combines language skills, business knowledge, and cross-cultural ability(Ellis, 2002).

Recent years, with the rapid development of marine economy and foreign trade, the demand for Business English talents has risen rapidly. During international communication, Business English plays an important role in foreign trade. It is used in many areas when negotiating, formulating agreements, signing contracts, etc. At the same time, the "One Belt and One Road" policy powerfully benefits the development of marine economy, especially in Zhoushan. The Business English major has a broad prospect. However, there are still many problems during the Business English talents training in China which will affect the employment of Business English major students to some extent.

First, the majority of universities and training organizations don't use original teaching materials, and have no clear teaching goals (Schleppegrell \&Royster, 1990). A lot of efforts and reforms have been made to improve the efficiency of teaching, but students' practical ability of using English language still remains poor(Song Jianqing, 2012). Teachers spend most of time explaining business vocabularies and international trade theories which are too abstract to be understood. Over time, students will gradually lose their interest. Secondly, traditional Business English courses are still similar to traditional English teaching. There is even no difference from common public English lessons in university. Compared with general English major students, Business English major students do not have comparative advantages. Third, most courses are teacher-centered (Gborsong, et al, 2015). Traditional teaching modes ignore students' needs during talents training and limit their future academic and career development. When it comes to real business after the students graduate, the learned knowledge become unusable.

\section{An EXPERIMENTAl Research on CURRENT Situation of CUltivating Business EngLish TALENTS IN ZHEJIANG OCEAN UNIVERSITY}

In this thesis, some researches are done on current situation of cultivating Business English talents in Zhejiang Ocean University. One is on students of Business English major in Zhejiang Ocean University through questionnaires to probe into current teaching deficiencies from students' perspective. The other research adopts telephone interview and live interview to analyze the demand of the enterprises of marine industries for Business English talents.

\section{A. Research on Students of Business English Major in Zhejiang Ocean University}

This research got 33 questionnaires from Business English graduates in Zhejiang Ocean University to obtain feedback on Zhejiang Ocean University's Business English teaching quality. The main contents of the questionnaire are about graduates' current working position, their evaluation of university' education on Business English, and their problems during work. Through this research, the authors aim to find out the actual employment situation of Business English graduates. After collecting the data and analyzing, marine universities can more easily adjust their Business English talents cultivating modes to enhance Business English graduates' competitiveness.

From the questionnaires, according to chart 1, when applying for a job, Business English graduates know little about the enterprise and are lack of relevant abilities.

CHART 1

THE PUZZLING FACTOR IN APPLYING FOR A JOB

\begin{tabular}{|l|l|l|}
\hline \multicolumn{3}{|c|}{ THE PUZZLING FACTOR IN APPLYING FOR A JOB } \\
\hline Options & Amount & Proportion \\
\hline Inadequate school career guidance & 10 & $30.3 \%$ \\
\hline Difference in major and job position & 12 & $36.36 \%$ \\
\hline Little known about the enterprise & 16 & $48.48 \%$ \\
\hline Lack of ability & 15 & $45.45 \%$ \\
\hline Others & 4 & $12.12 \%$ \\
\hline
\end{tabular}

According to chart 2, most of the graduates reflect that their lack of English language skills(listening, translation, reading, speaking, writing, etc.), business operation skills(international trade terms, documents, quotations, etc.) and cross-cultural business communication skills( business etiquette, business negotiation, etc.).

CHART 2

SKILL NEEDED MOST IN WORK

\begin{tabular}{|l|l|l|}
\hline Options & Amount & Proportion \\
\hline $\begin{array}{l}\text { A. Language skills (listening, translation, reading, speaking, } \\
\text { writing, etc.) }\end{array}$ & 16 & $48.48 \%$ \\
\hline $\begin{array}{l}\text { B. Business operation skills (operation of international trade } \\
\text { terms, documents, quotations, etc.) }\end{array}$ & 14 & $42.42 \%$ \\
\hline $\begin{array}{l}\text { C. Business theoretical knowledge (international trade terms, } \\
\text { documents, international cargo transportation, etc.) }\end{array}$ & 12 & $36.36 \%$ \\
\hline $\begin{array}{l}\text { D. Cross-cultural business communication skills (business } \\
\text { etiquette, business negotiation, etc.) }\end{array}$ & 13 & $39.39 \%$ \\
\hline \begin{tabular}{l} 
E. Others \\
\hline
\end{tabular} & 4 & $12.12 \%$ \\
\hline
\end{tabular}


According to chart 3, the majority of graduates also reflect the importance of communication skills, problem-solving skills and Business English relevant knowledge.

CHART 3

THE MOST IMPORTANT SKILLS IN WORK

\begin{tabular}{|l|l|l|}
\hline Options & Amount & Proportion \\
\hline A. Business English major knowledge & 21 & $63.64 \%$ \\
\hline B. Responsibility & 12 & $36.36 \%$ \\
\hline C. Communication skill & 28 & $84.85 \%$ \\
\hline D. Innovation & 8 & $24.24 \%$ \\
\hline E. Teamwork & 18 & $54.55 \%$ \\
\hline F. Ability to solve problems & 25 & $75.76 \%$ \\
\hline
\end{tabular}

They also put forward some suggestions on the talents training modes. One is to provide practical training, the other one is to train their ability on computer to develop students' competitiveness.

\section{B. Research on Demand of Zhoushan Local Maritime Enterprises for Business English Talents}

In this research, we interviewed six marine related enterprises in Zhoushan which have demand for Business English talents. The purposes of the research on Zhoushan local maritime enterprises are mainly as follows:

- Investigate the needs for Business English talents in Zhoushan marine industries, and solve the problem that enterprises can not "go out" because of the shortage of Business English talents, thus to promote the development of Zhoushan marine industries.

- Provide reliable data for relevant government departments in Zhoushan so that the government departments can carry out specific policies to promote the development of Zhoushan Free Trade Zone and the rapid implementation of the "One Belt and One Road".

- Provide reference for marine universities and related training institutions to train compound Business English talents.

- Provide reference for marine universities' Business English major students to encourage them to learn more relevant professional skills so that they can get more opportunities to get better employment.

The findings of the research are based on the interviews. And enterprises' needs and requirements for Business English graduates can be concluded as follows:

- Generally speaking, the enterprises don't emphasize much on employees' educational background. Some managerial positions such as managers and supervisors may require higher degrees. Although the requirements for educational background are not high, most of positions require working experience. It may be adverse for current graduates.

- The requirements of employees' English ability are mainly determined by the nature of the work. Most enterprises require Business English graduates to have good English listening and speaking ability and effective business communication skill with CET-4 certificate or even CET-6. Enterprises also put forward certain requirements on the computer capabilities that graduates should be proficient in office software.

- For different positions, there are other specific requirements. For example, foreign trade clerks should be familiar with the process of foreign trade business and have the ability to do business operations independently. The foreign trade document specialists shall be familiar with business activities in connection with documentary.

- The comprehensive quality requirement of the employees is one of the aspects that enterprises pay much attention to. It can be reflected in employees' working attitude, working ability, communication ability, etc. It can be specifically expressed as: hard working, confident, responsible, innovative, cooperative, broad-minded and so on.

Besides, as to the current Business English training modes, the enterprises put forward some suggestions for reference to universities:

- Universities should set up clear teaching target and requirement for students' general abilities, and distinguish different knowledge and skills for different positions.

- Strengthen students' oral English training, and develop their ability to communicate in English. Students should obtain CET-4 and CET-6 certificate, as well as professional certificates, such as TEM-4, TEM-8, BEC. Students' business management skills shall also be developed which will benefit them for their career in the long term.

- Improve the comprehensive quality of students and cultivate students with good ethics. Graduates should not only have good professional ability, but also sound personality. Encourage students to take part in social activities such as competitions and volunteer activities during holidays.

- Strengthen cooperation with enterprises to achieve close interaction. Students should do internship in advance, to help them recognize their advantages, and find the job orientation for the future.

\section{Analysis of the Research Results}

From the research on Business English graduates, the author finds out that, when it comes to job hunting, the majority of graduates believe that effort and careful preparation will bring opportunity. It can be shown that the demand for Business English graduates is relatively large. The graduates have promising employment prospects and optimistic employment situation. The majority of graduates think that they are competent for their work and they are making constant progress by studying and practicing. For graduates, sometimes it is more important to achieve practical 
opportunities and gain working experience rather than care about salary when they first start to engage in foreign trade. Also graduates find that spoken English is very important during their work, but they seemed to practice little in class. At the same time, some specialized courses, such as Foreign Trade Correspondence, International Trade Affairs are very useful during their present work. Besides, interpersonal skills, social etiquette and computer proficiency are considered to be important in their daily work.

From the research on enterprises of Zhoushan marine industries, it can be seen that, the enterprises have little demand for Business English talents. They seldom distinguish students between English major and Business English major in the recruitment. One of the reasons is that, in the view of them, both Business English major students and English major students have basic English ability to listen, speak and write English. What the enterprises value most are students with good English language skills, especially spoken English, and business operation and communication skills. Business English students can not stand out. The second reason is the problem of the curriculum of Business English major. The Business English training is still at exploring stage. There are still problems like insufficient teaching and poor teaching resources. Enterprises of marine industries, such as shipping agent and forwarder shipping agent, have professional business terminology which Business English major students have not studied systematically. Thirdly, many Business English major students are confused about what Business English major should focus on. Most students pay too much attention to language learning instead of business operation skills.

The results of the two researches are important basis for the curriculum development and reform in the future, and are valuable reference. To meet the requirements of the enterprises, the training modes of Business English major need to be improved.

\section{Suggestions on Cultivating Business English TAlents of Maritime University}

When cultivating Business English talents, we must pay attention to the comprehensive training of business operation skills, language skills and cultural customs. Business English talents should be familiar with capricious international business environment, and participate in international market with more professional knowledge. And in this thesis, there are mainly three suggestions on cultivating Business English talents of maritime universities, those are, adjusting teaching materials and innovating courses, strengthening the second foreign language teaching, and strengthening the cooperation between university and enterprise.

\section{A. Adjusting Teaching Materials and Innovating Courses}

Appropriate teaching materials can broaden learners' major knowledge, develop their ability of communication and practice, motivate their learning interest and promote them to raise the ability of self-study, so as to cultivate high-quality Business English talents to fulfill the need of the new century. In the past 20 years, the construction of Business English teaching materials in our country has developed rapidly. There are numerous series of Business English teaching materials in publishers. However, most of them sold in the market have disadvantages, such as inaccuracy, obsolescence and incompatibility, There is a lot to be improved.

Professional teaching materials should be practical, pertinent, informative, communicative, interesting and scientific. Appropriate Business English teaching materials should focus on practicability, equipped with a large number of practical training of language skills and business skills. The content should be real and novel, keep pace with the era, and fully reflect the international business activities. The materials should contain business culture and cross-cultural communication skills which are the key to determining the success of business activities and are vital parts of Business English teaching. The teaching materials must contain teachers' books, students' books, multimedia courseware, training software and database of exercises which benefit class teaching from multi-aspect and raise students' interest of self-learning to shift the teaching center from teachers to students.

Traditional general higher education is based on disciplines. It focuses on the teaching of comprehensive and systematic theoretical knowledge. Theoretical teaching occupies a large part of the curriculum, which leads to weak practical ability of students. According to the teaching objectives of Business English majors, Business English teaching should change the traditional way, and it should take the career requirements of the students as the center. It is important to achieve a transition from simply teaching English and business theory to training business employment skills and innovation capabilities, and build a curriculum system that focuses on cultivating students' abilities in application.

ESP is defined as an approach to language teaching in which all decisions as to content and method are based on the learner's reason for learning (Hutchinson \&Waters, 1987). So Business English courses should be different from traditional courses. Traditional courses are defined as one way, that is teacher's teaching to students. New courses should be summarized as two-way, that is interaction between teacher and student during study. Teacher should provide students both knowledge in the text and varied activities, including business negotiation simulation, presentation, etc. The courses should aim at cultivating students' application ability by integrating and optimizing teaching content, merging and deleting repetitive, overlapping, similar and outdated content. Teachers should focus on adopting flexible and diverse teaching methods such as heuristic learning, interactive learning, discussion, case analysis, scenario simulation, role-playing and project teaching. At the same time, teachers can carry out various forms of teaching 
activities to stimulate students' interest. Teachers should make full use of modern teaching methods such as multimedia, network, and training software to achieve three-dimensional teaching and teaching efficiency.

\section{B. Strengthening the Second Foreign Language Teaching}

The second foreign language teaching is one of the important parts of Business English teaching. With the increasing demand for foreign language talents in the society, more and more attention has been paid to it. The second foreign language is considered as the enhancement of students' ability. Most universities set courses of the second foreign language, which are Japanese, French, and Russian. Students can master certain regularities and grasp the internal connection of language learning when learning the second foreign language. Zhoushan has advantages as an excellent port city. Its superior geographical location and abundant foreign trade resources attract more and more enterprises from all over the world to come to Zhoushan. It has been proved that foreign language talents who master bilingual languages are more competitive than others.

Nowadays, with the development of globalization, learning multiple languages has become a certain trend. While learning a language, we are also learning its culture. The new linguistic learning helps us to understand the differences in culture so that we can have a good understanding of ideas from the other perspective. Learning a second language can enable us to look at problems from different perspectives and to solve problems more creatively. As a tool for communication, learning a second language is the process of training the brain to accept new ideas and new knowledge, it can improve the cognitive ability and memory.

Learning a second foreign language can bring more employment options for Business English major students. The severe employment situation makes graduates realize the importance of multi-language and multi-disciplinary learning. Through learning the second foreign language, Business English major students can develop their language skills. More importantly, with language as a tool, students can play a promoting role in various fields, make the country's technology, culture and knowledge be clearly expressed to other countries.

\section{Strengthening the Cooperation between University and Enterprise}

Strengthening the cooperation between university and enterprise can achieve a seamless transition from courses to practice, and provide students opportunity to participate in business operations. Building a diversified, multi-level training system that combines courses and practical training will train students with unique valuable experiences to make best use of the contents and skills learned in the classroom. This kind of teaching method focuses on the real business environment and provides students specific tasks, such as how to deal with customers' complaints, how to negotiate a contract, etc.

The training projects should be based on the marine industries in Zhoushan so that students can experience in the real business in advance to develop their Business English operation ability. On the one hand, the training is similar to students' future work. The experience can benefit students' career in the future. On the other hand, it can train students' cooperative ability, improve their communication skills, and cultivate their professionalism. By training in the foreign trade enterprises of marine industries, traditional Business English teaching can better transferred from theoretical teaching to practical teaching.

It is also essential to strengthen the construction of teaching staff and cultivate dual-qualified teachers. Teachers can participate in business training related to Business English major to enhance their professional skills so as to improve teaching effectiveness. By training in the real business, teachers can have a better understanding of the knowledge from books and real business operation. It can make up for the deficiencies that the teachers do not understand business and foreign trade knowledge, and it can change the situation that teachers just teach students theoretical things.

It is another powerful measure to cultivate Business English talents by enterprises providing courses to students. The enterprise staff with much experience in the business environment deliver the courses to students. They can use their ability of foreign trade in their work fluently and know much about how to deal with real business. Compared with traditional courses, students can learn more about enterprise culture, business operation and problems dealing in this way, they can have a better understanding of what their future work is about and get prepared in advance.

On July 27, 2017, Putuo Professional Education Group in Zhoushan was established covering resources of education, tourism, business, and media. Its establishment is the further cooperation between university enterprise and student to achieve resource sharing, market sharing, information sharing and even talents sharing. It can help to build a close university-enterprise cooperation community which can achieve win-win situation. The establishment of Putuo Professional Education Group plays an effective role in promoting the cooperation between university and enterprise. In the future, it can help to develop projects including teachers learning in enterprises, students practising in enterprises, enterprises providing courses to students, etc.

\section{CONCLUSION}

In conclusion, this thesis takes Zhejiang Ocean University as an example based on exploration of existing problems in the training modes of Business English talents in marine universities and put forward some suggestions and opinions for reference. The thesis actively explores innovative modes for the cultivation of Business English talents, helps to optimize the setting of Business English courses, and strengthens the practical training to improve the practical 
application ability of Business English students to adapt to the rapid development of China's marine economy and the changing needs of the talent market.

However, due to the author' limited ability, some specific problems have not been solved yet. For example, some enterprises may not be willing to cooperate with universities. Besides, it may be difficult to see significant results in a short period of time. This research is still in its infancy and requires a lot more time. And the author will do more researches if further exploration is needed.

\section{APPENDIX. QUESTIONNAIRE FOR BUSINESS ENGLISH GRADUATES}

1. What is your current job position?
A. Foreign trade
B. English teaching
C. Translation
D. Business assistant and secretary
E. Others

2. What do you think is the most puzzling factor in applying job?
A. Inadequate school career guidance
B. Difference in major and job position
C. Little known about the enterprise
D. Lack of ability

3. Have you ever met problems caused by inadequate major knowledge during your work?
A. Yes
B. No

4. What do you think are the reasons of problems during work due to inadequate major knowledge?
A. My own reason
B. The knowledge hasn't been taught in class
C. Other reasons

5. Which skill do you lack most?
A. Language skills (listening, translation, reading, speaking, writing, etc.)
B. Business operation skills (operation of international trade terms, documents, quotations, etc.)
C. Business theoretical knowledge (international trade terms, documents, international cargo transportation, etc.)
D. Cross-cultural business communication skills (business etiquette, business negotiation, etc.)
E. Others

6. What do you think should be the center of Business English teaching?
A. Language skills (listening, translation, reading, speaking, writing, etc.)
B. Business operation skills (operation of international trade terms, documents, quotations, etc.)
C. Business theoretical knowledge (international trade terms, documents, international cargo transportation, etc.)
D. Cross-cultural business communication skills (business etiquette, business negotiation, etc.)
E. Others

7. Which skill do you think enterprises value most?
A. Language skills (listening, translation, reading, speaking, writing, etc.)
B. Business operation skills (operation of international trade terms, documents, quotations, etc.)
C. Business theoretical knowledge (international trade terms, documents, international cargo transportation, etc.)
D. Cross-cultural business communication skills (business etiquette, business negotiation, etc.)
E. Others

8. Please select three of the most important skills in work?
A. Business English major knowledge
B. Responsibility
C. Communication skill
D. Innovation
E. Teamwork
F. Ability to solve problems

9. Please select three of the most important certificates to apply for work?
A. Customs Broker Certificate
B. Tour Guide Certificate
C. BEC Certificate
D. Certificate for Documentary Credit Specialists
E. Secretary's Certificate
F. Second-level Certificate for National Computer
G. Logistics Certificate
H. CET-4 and CET-6 


\section{TEM-4 and TEM-8}

J. Teacher qualification certificate

K. Others

10. What advice do you have for current Business English talents training?

\section{REFERENCES}

[1] Ellis, M. (2002). Teaching Business English. Shanghai: Shanghai Foreign Language Education Press.

[2] Gborsong, P. A., et al. (2015). A Needs Analysis of Undergraduate Students of Communicative Skills: The Case of Tertiary Instituions in Ghana. Open Journal of Modern Linguistics, 5, 413-424.

[3] Hutchinson, T. \&Waters, A. (1987). English for Special Purpose. Cambridge: Cambridge University Press.

[4] Schleppegrell, Mary. \&Royster, L. (1990). Business English: An international survey. Science Direct, 9, 3-16.

[5] Song Jianqing. (2012). Talent Training in Business English in China under the Background of China-ASEAN Free Trade Area. Around Southeast Asia, 6, 60-70.

Xuanqi Wang was born in Zhejiang, China in 1996. She received her bachelor's degree in Business English from Zhejiang Ocean University in 2018.

She joined the Internship at the Youth League Committee in 2017 in Putuo district, Zhoushan.

Ms. Wang's Research of the Employment Orientation of Business English Major was published on Management Observer in 2016.

Fangjie He was born in Zhejiang, China in 1984. She received her master's degree in applied linguistics from Shanghai University of International Business and Economics in 2010.

She is currently a lecturer in the School of Foreign Languages, Zhejiang Ocean University, Zhejiang, China. Her research interests include business English teaching. 